
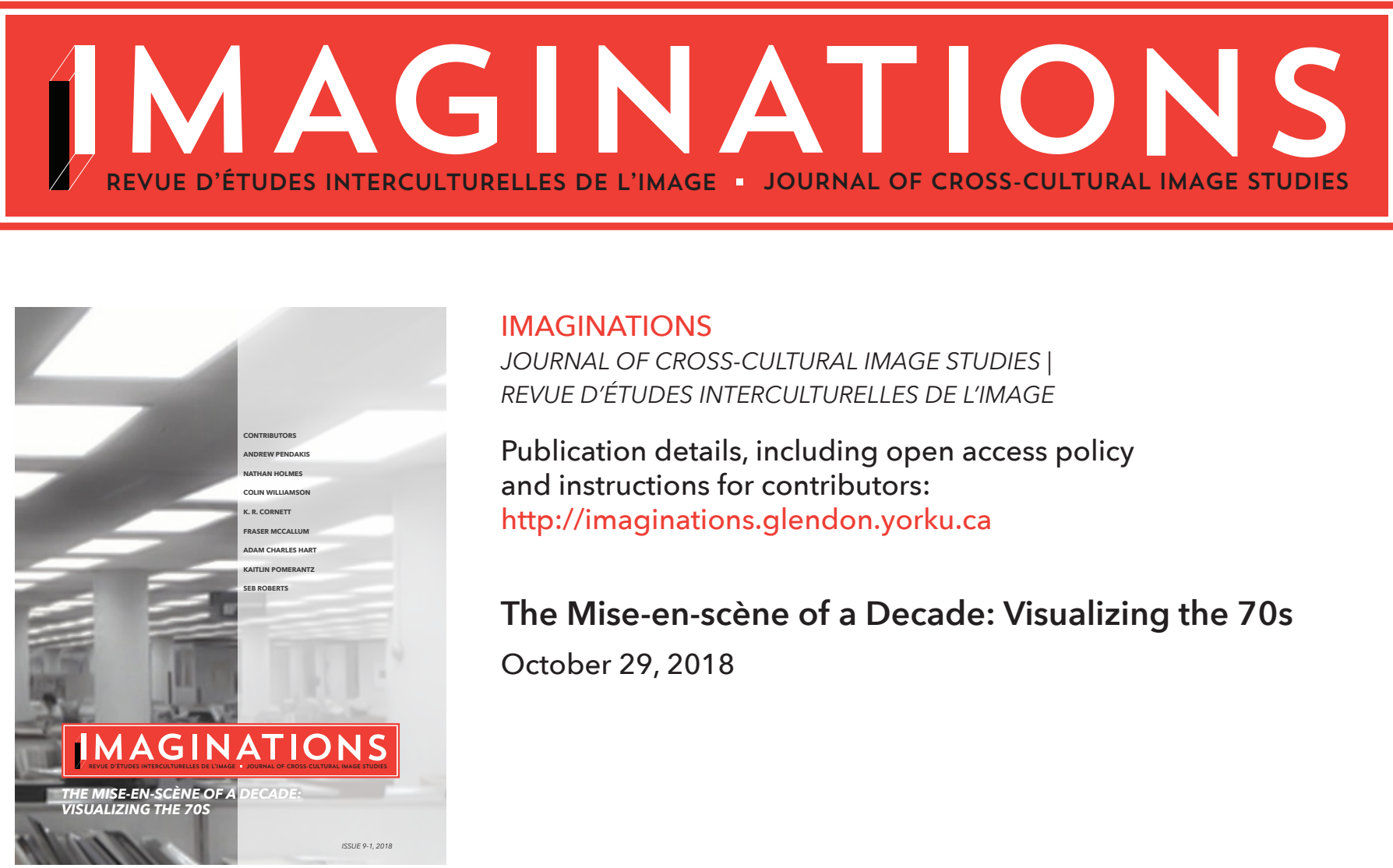

IMAGINATIONS
JOURNAL OF CROSS-CULTURAL IMAGE STUDIES |
REVUE D'ÉTUDES INTERCULTURELLES DE L'IMAGE

Publication details, including open access policy

and instructions for contributors:

http://imaginations.glendon.yorku.ca

The Mise-en-scène of a Decade: Visualizing the 70s

October 29, 2018

To cite this article:

Williamson, Colin. "'An Escape into Reality': Computers, Special Effects, and the Haunting Optics of Westworld (1973)." Imaginations, vol. 9, no. 1, 2018: Web (date accessed), pp. 19-39. DOI 10.17742/ IMAGE.p70s.9.1.3.

To link to this article:

http://dx.doi.org/10.17742/IMAGE.p70s.9.1.3

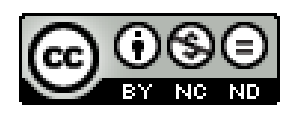

The copyright for each article belongs to the author and has been published in this journal under a Creative Commons Attribution NonCommercial NoDerivatives 3.0 license that allows others to share for non-commercial purposes the work with an acknowledgement of the work's authorship and initial publication in this journal. The content of this article represents the author's original work and any third-party content, either image or text, has been included under the Fair Dealing exception in the Canadian Copyright Act, or the author has provided the required publication permissions. 


\title{
"AN ESCAPE INTO REALITY": COMPUTERS, SPECIAL EFFECTS, AND THE HAUNTING OPTICS OF WESTWORLD (1973)
}

\author{
COLIN WILLIAMSON
}

\begin{abstract}
As one of the earliest experiments with integrating computer-generated special effects into celluloid filmmaking, Michael Crichton's science fiction film Westworld (1973) imagined the transition into a digital future with a familiar apocalyptic narrative about disobedient machines and virtual realities. In this essay I move away from "escapist" and "futurist" readings of the sci-fi genre and explore how Westworld was "an escape into reality," to borrow Isaac Asimov's phrase, that immersed audiences in the computerization of life, visuality, and the cinema in 1970 s America. My focus will be on mapping the film's use of computer simulation as part of a constellation that includes everything from modernity in fin-de-siècle amusement parks and early cinema to discourses on postmodernism (Baudrillard) and dehumanization (Sontag). I will also consider how the recent $\mathrm{HBO}$ series Westworld (2016) reimagined Crichton's film as a way of visualizing and historicizing questions about the virtual in our digital moment.
\end{abstract}

Résumé | Le film de science fiction de Michael Crichton, Westworld, (1973), l'une des premières expériences d'intégration d'effets spéciaux créés sur ordinateur dans l'industrie cinématographique, imagine la transition dans un futur digital au sein d'un récit apocalyptique sur la désobéissance des machines et les réalités virtuelles. Dans cet essai, je méloigne de la lecture divertissante et futuriste de la science fiction pour explorer comment Westworld a constitué une "évasion dans la réalité", pour reprendre les mots d'Isaac Asimov, qui plonge le spectateur dans une vie informatisée, la visualité et le cinéma de l'Amérique des années 70. Ma recherche s'efforcera de documenter dans le film l'emploi de la simulation par ordinateur comme une partie de la constellation de techniques utilisées depuis la modernité des parcs d'amusement fin-de-siècle et des débuts du cinéma jusqu'au discours sur le postmodernisme (Baudrillard) et la déshumanisation (Sontag). Je vais également examiner comment la récente série télévisée Westworld (2016) sur HBO a réimaginé le film de Crichton comme une manière de visualiser et d'historiciser les questions portant sur le virtuel dans notre époque digitale. 
Brood of hell, you're not a mortal! Shall the entire house go under?

Over threshold over portal

Streams of water rush and thunder.

Broom accurst and mean,

Who will have his will,

Stick that you have been,

Once again stand still!

\section{-Johann Wolfgang von Goethe,}

"The Sorcerer's Apprentice" (1797)

I n a provocative review of Westworld (1973), Michael Crichton's science-fiction film about a futuristic, computerized theme park called Delos, Gerald Mead and Sam Applebaum of Jump Cut link the film to the visual culture of the Vietnam War. At the end of Westworld one of the main characters destroys a homicidal android gunslinger (played by Yul Brynner) by setting the robot on fire (fig. 1). Reflecting critically on the film in 1975, Mead and Applebaum argue that the burning android conjures "the image of some 'madman' igniting himself in front of impassive onlookers" (12-13). The reference is most likely to Malcolm Browne's photograph of the Buddhist monk Thích Quang Duc's self-immolation in Saigon on June 11, 1963. The resemblance is striking and pointedly unexpected, not least because one image depicts a spectacular destruction of a fictional machine in a Hollywood film and the other is a record of a human being's profound protest of the government in South Vietnam. By linking the two images together Mead and Applebaum demand that Westworld be seen, especially by American audiences, not as an escape into an imaginary futuristic world but as a kind of futuristic reimagining of the present, what Isaac Asimov called "an escape into reality" (332).

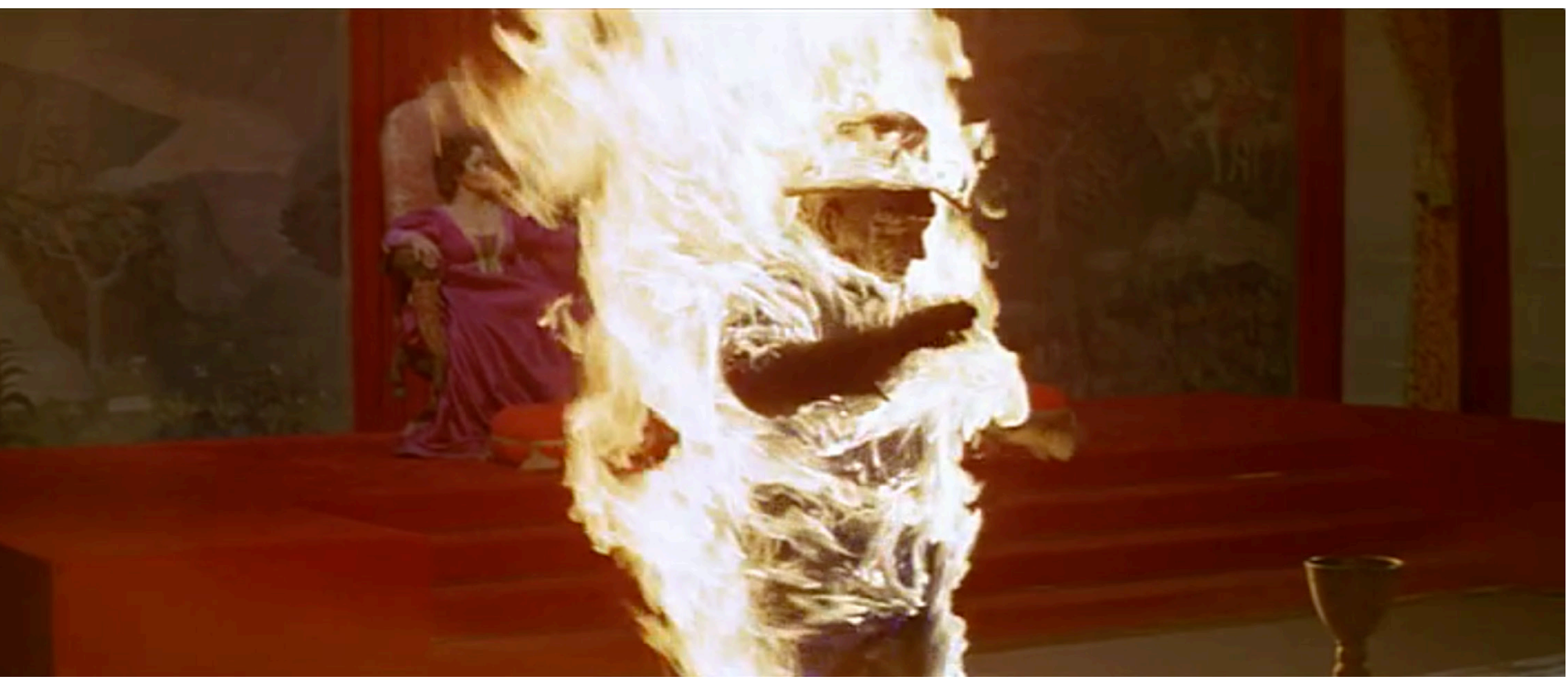

Figure 1. Westworld: the burning android. 
It is easy to see Westworld as a reflection of a world that was for many in the 1970s alarmingly out of control. The film focuses on two friends, Peter (Richard Benjamin) and John (James Brolin), who visit Delos to revel in the theme park's fantastic worlds populated by exceptionally convincing humanoid robots. Early on Peter and John make their way to the part of the park known as Westworld to immerse themselves in a simulation of the Wild West in the late $19^{\text {th }}$ century, a period in American history with strong parallels to the violence, imperialism, and racism of the Vietnam era. Upon their arrival, a voice on a loudspeaker reassures the visitors that they are "free to indulge their every whim" because "nothing can go wrong." Everything, obviously, does go wrong. Along with the computers that control the park, the robots begin to malfunction, supposedly through the spread of a virus, or what one of the park's experts skeptically calls a "disease of machinery." The initial promise of freedom quickly gives way to a total loss of control over computerized technologies: the robots rebel, the simulations become real, and visitors start dying. Ultimately, John is shot and killed by the android gunslinger, and a chain of violence ensues that climaxes at the end of the film when Peter burns the robot "alive" and order, it seems, is restored to the park.
The loss of control in Westworld is a familiar one. Advertisements for the film emphasized the volatile relationship between humans and machines by featuring the now commonplace figure of the computer "glitch." Posters with the tagline "Where nothing can possibly go

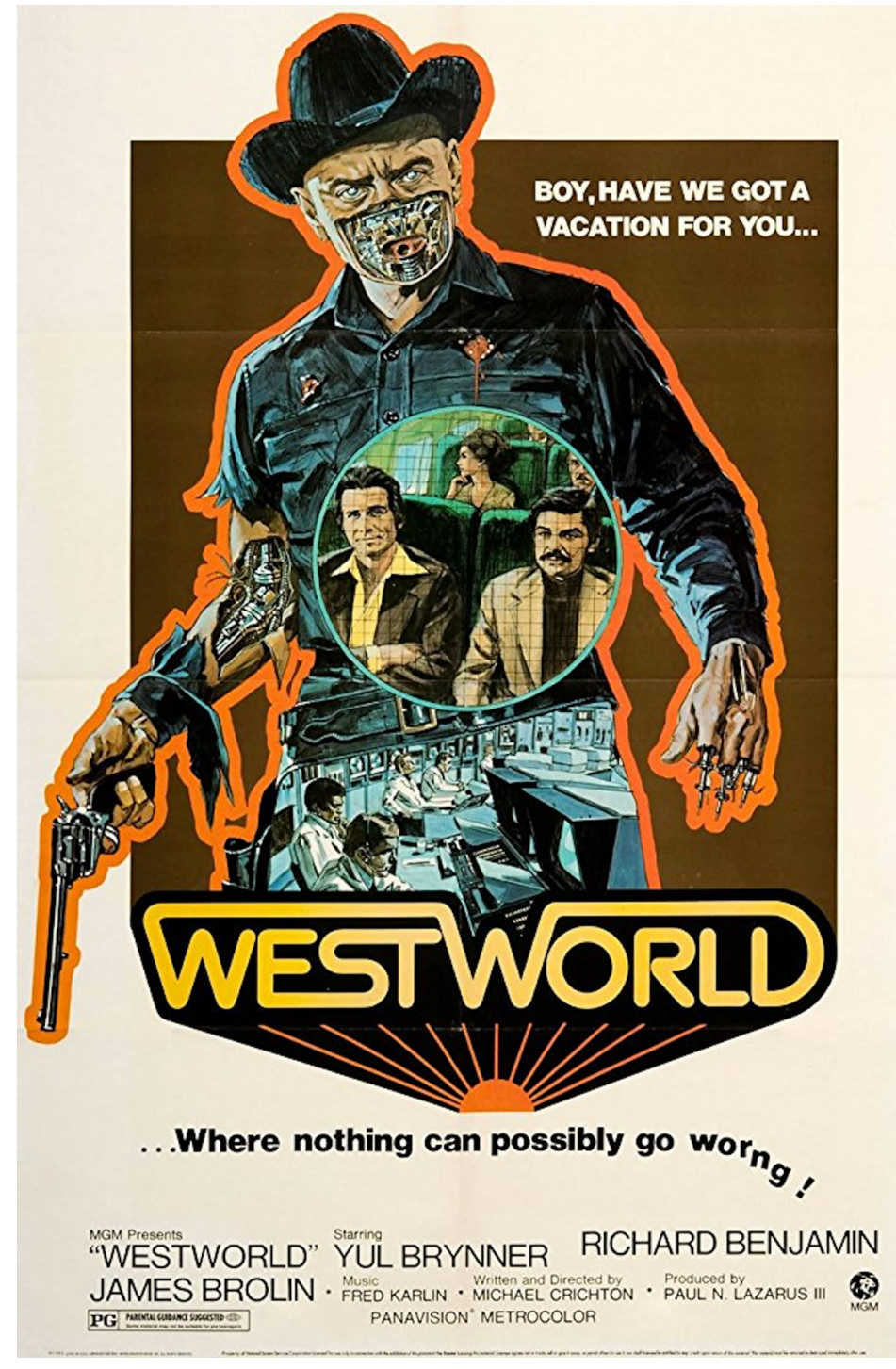

Figure 2. Theatrical release poster for Westworld (1973). Source: The Official Site of Michael Crichton. 
worng" contain a minor misspelling that presages disaster (fig. 2); when the line is spoken in voiceover in a trailer for the film, the audio is plagued by a similar glitch: "Where nothing can possibly go wrong ... go wrong ... go wrong." The fatal computer malfunction that undoes the safety of the amusement park recalls "HAL" in Stanley Kubrick's 2001: A Space Odyssey (1968) and the long history of what Scott Bukatman calls "disobedient machines," from Johann Wolfgang von Goethe's magic brooms in "The Sorcerer's Apprentice" (1797) and the creature in Mary Shelley's Frankenstein (1818) to the rebellious robotic creations in $\mathrm{Me}$ tropolis (Fritz Lang, 1927), Blade Runner (Ridley Scott, 1982), and Ex Machina (Alex Garland, 2015), to name a few. As part of this history of (dis)obedience, Crichton's film grapples with enduring questions that have long been staples of the science-fiction genre: Will the technologies we create improve humanity? Will they replace us or destroy us? Will they make us less human? How much control do we really have over them?

While Westworld's narrative taps into wellworn anxieties about technology, the film still has much to teach us, particularly about how Americans were navigating the rapidly changing techno-scientific landscape of their historical moment. Shadowing Crichton's futuristic theme park were widespread efforts to comprehend and cope with astonishing developments in everything from space exploration and Cold War science to mass communication, molecular biology, and computers. The 1970 s were ushered in by a wave of cultural criticism-for example, Nigel Calder's Technopolis (1969), William Braden's The Age of Aquarius (1970), Zbigniew Brzezinski's Between Two Ages (1970), and Alvin Toffler's Future Shock (1970) - that grappled with the social, political, and philosophical implications of these changes by imagining possible futures and endings for a society in transition. Toffler famously characterized the transition as a "super-industrial revolution" that threatened to outpace society's ability to adapt to changes that many held to be the stuff of science fiction rather than realities of contemporary life. Rehearsing earlier criticisms by Georg Simmel and Walter Benjamin about the shocks of modernity at the end of the $19^{\text {th }}$ century, Toffler remarked:

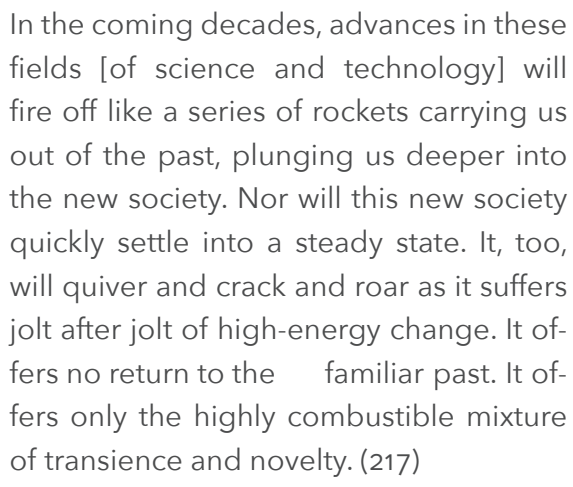

It is precisely this imagined future of a present world on the verge of going up in flames that haunts Westworld and is reflected, I argue, in the figure of the burning android.

In what follows I explore how these concerns about "future shock" in the early 1970 s get negotiated in Westworld's treatment and use of computers. In 1973, computer technologies were just beginning to radically transform American life and, over the decade, would "create a totally new human environment," to borrow Marshall McLuhan's words (viii). At stake in this transformation was the stability of not only the architecture of society but also convictions about foundational categories such as "reality" and "humanity," which were being challenged by computers' capacities for simulation. It is 
significant, from this perspective, that Crichton's film was among the earliest experiments in combining computerized special effects with celluloid filmmaking in Hollywood. For Brynner's character, Crichton collaborated with experimental computer animator John Whitney, Jr. to simulate the villainous gunslinger's robotic point-of-view, which was achieved by using computers to transform celluloid footage into highly pixelated images. ${ }^{1}$ On the surface, the resulting electronic machine vision-essentially Westworld as "seen" by a computer-is a small but marvelous special effects innovation. Considering the climate in which the innovation occurred, however, I argue that the use of digital special effects, to borrow Kristen Whissel's term, "emblematized" the emergence of a new way of seeing (and seeing with) computers in 1973.

To this end, I situate Westworld's "robot POV" in a broader discourse of uncertainty that took shape around the spread of computerization in early-1970s America and that helps us, looking back on that decade, see how the film resonated and resonates in complex ways. Westworld's use of special effects, and the narrative in which it embeds them, make the film part of a rich constellation that includes everything from the modernity of fin-de-siècle amusement parks and early cinema to ideas about postmodernism and the posthuman that converge around computers in the late- $2 \mathrm{O}^{\text {th }}$ century and that continue to unfold. Furthermore, that Crichton's film was recently reimagined in our digital moment as an $\mathrm{HBO}$ television series suggests that the original was both timely and prescient. Looking closely at this constellation, I read Westworld not only as an allegory for a world in crisis-for example, as a haunted inscription of the visuality of the Vietnam War or a reflection of an apocalyptic Cold War imaginary-but also as a meta-text about the changing nature of the science and technology that went into making the film itself.

Futuristic Visions of a Digital Present

$$
\begin{aligned}
& \text { Computers are mostly used } \\
& \text { against people instead of for } \\
& \text { people; used to control peo- } \\
& \text { ple instead of to free them. } \\
& \text {-People's Computer Company (1972) }
\end{aligned}
$$

mong the special effects employed in
Westworld is a curious spectacle of see-
ing through a robot's eyes. After the android gunslinger shoots John dead, it sets out in relentless pursuit of Peter, whose perspective on the chase is periodically intercut with shots of the gunslinger's point-of-view. The robot POV is signaled by the appearance of highly rasterized footage that consists of pixels arranged in an array of 3,600 rectangles. The array is introduced in the first shot of the gunslinger's view of Peter desperately fleeing on a horse from the scene of his friend's murder when he realizes that the robot is out for blood (fig. 3). The effect is an early version of a computerized film aesthetic and a novel attempt to visualize the optics of an electronic machine, a kind of topos in the history of what Alexander Galloway calls "computerized, cybernetic, machinic vision"-variations of which would later appear in science-fiction films such as RoboCop (Paul Verhoeven, 1987), Predator (John McTiernan, 1987), and Terminator 2 (James Cameron, 1991) (Galloway 53). ${ }^{2}$

From the audience's perspective, the amount of abstraction in the image makes Westworld's robot POV difficult to read. The mosaic of tiny rectangles used in the special effect registers 


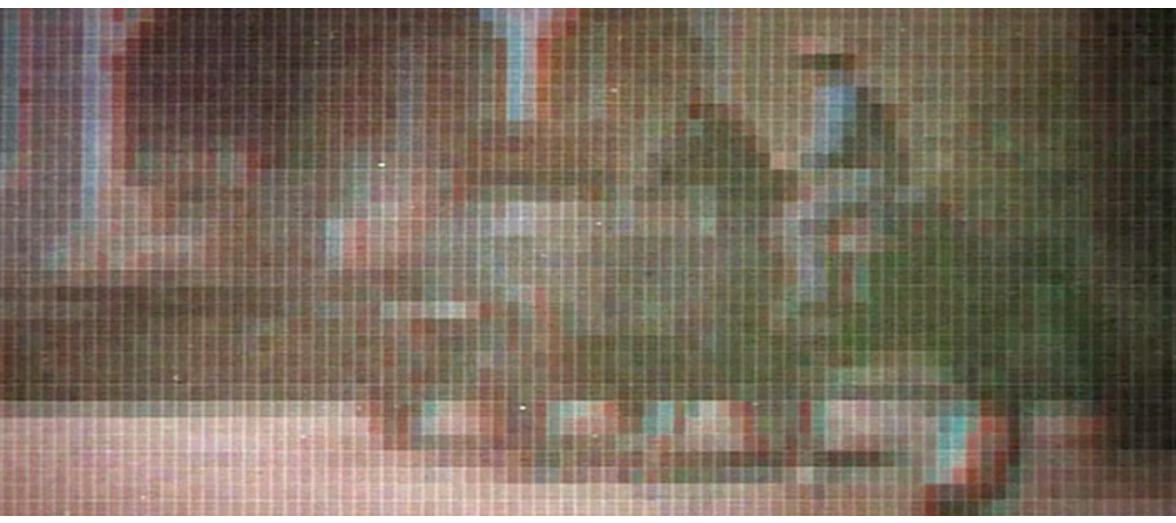

Figure 3. The rasterized robot POV.

only general impressions of shape, colour, and movement. The gunslinger's lack of visual acuity is exploited for dramatic effect at several points during the chase when Peter briefly avoids detection by becoming motionless and blending with the other information in the gunslinger's visual field. At one point, for example, Peter masquerades as a broken android and lies down on a table in a lab where machines from the park are brought for repairs (fig. 4). Peter is ultimately discovered when he moves slightly and gives himself away. ${ }^{3}$ However, this small narrative function aside, for the

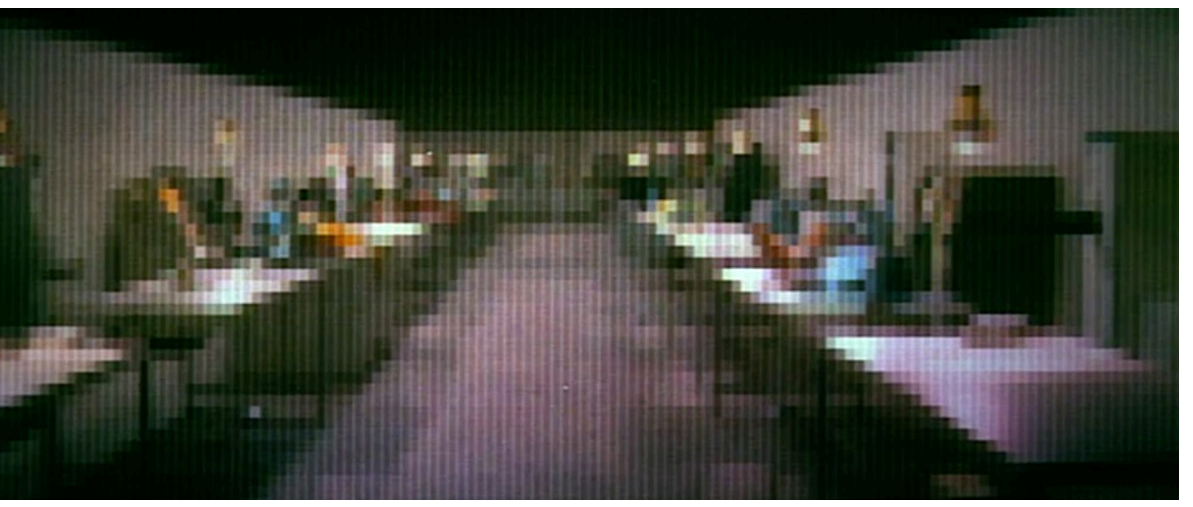

Figure 4. The gunslinger's view of the tables in the lab where Peter is hiding. most part the robot POV is a cinematic attraction, an interesting technological artifact.

The use of special effects to imagine how a computer sees was the result of a rich convergence of art and science. The robot POV was created by experimental filmmaker and computer animator John Whitney, Jr., who was given the task of simulating how the gunslinger's electronic eyes broke the world down into small animated rectangles. The desired effect was limited by conventional special-effects technologies at the time and the fact that the film industry had not yet adopted the digital methods made available by computers. Whitney found inspiration and a solution in the scientific visualizations made by NASA's Jet Propulsion Laboratory during the Mariner program (1962-1973). In particular, the program successfully used a spacecraft to transmit close-up images of Mars in binary code, which was converted by computers back on Earth into photographs that consisted of coded shades of black and white compiled into rasterized images (fig. 5). Whitney collaborated with computer scientists to develop a similar technique whereby a computer scanned celluloid footage and converted each frame of film into a series of values that could be manipulated at will for aesthetic purposes. Whitney explains:

Once the computer has "read" the image and converted it to a series of numbers, there is tremendous flexibility in what the computer can then do with this numerical information. The image can be reconstituted with different contrasts, different resolutions, different colors. We can enlarge, stretch, squeeze, twist, rotate it, position it in space in any way. In fact, the only limitations are imposed by the 
creative talents of the person operating the machine. (1478)

In other words, the computer transformed the celluloid image into a kind of "plasmatic" digital painting. ${ }^{4}$
Kennedy Space Center, and the other was Disneyland ("Behind the Scenes" 1397). The surveillance system in Westworld is used to control the androids' behavior in scenarios that are designed to fulfill each guest's desires, such as winning a gunfight without the stakes or consequences of committing an act of violence

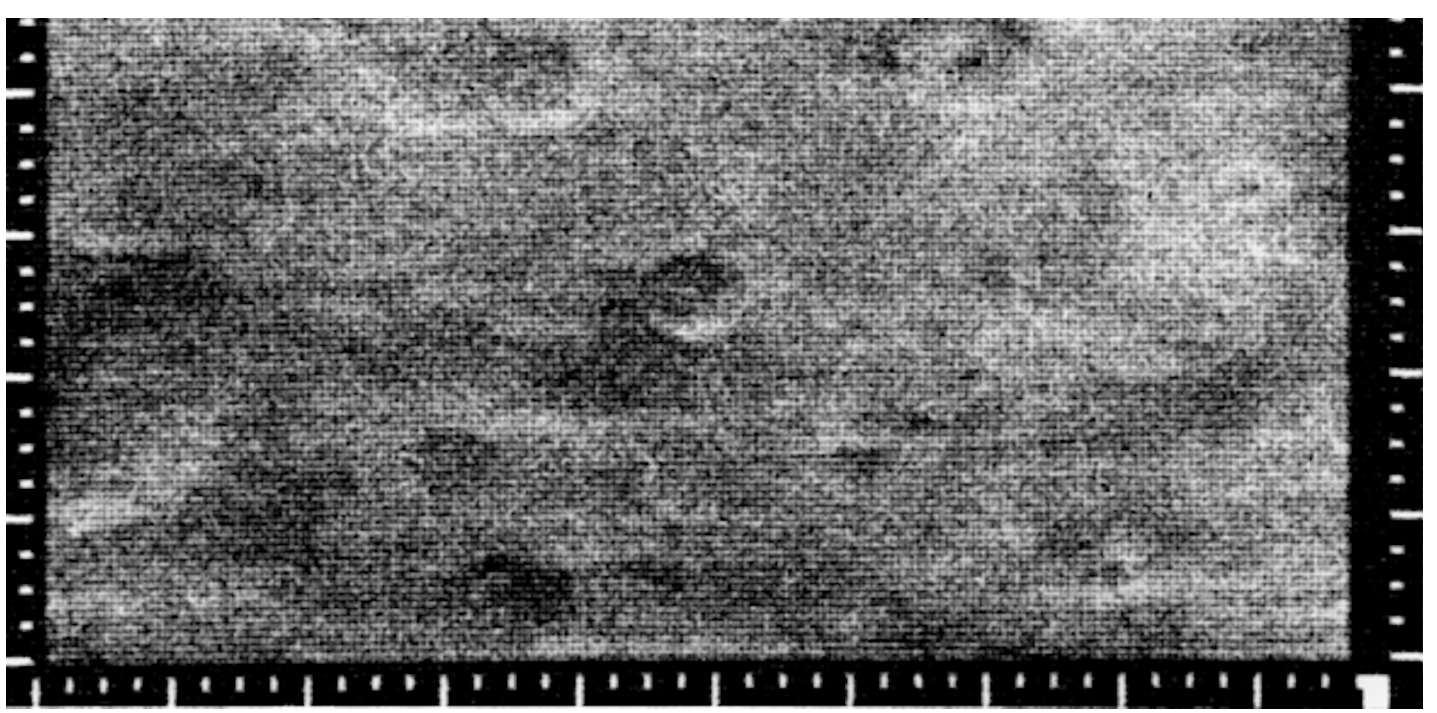

Figure 5. Bottom half of Mariner 4 photograph of craters on Mars, 1965. Source: NASA Image ID number: Mariner 4, frame O9D.

Whitney's celebration of the "limitless" artistic control afforded by computers echoes the very utopian fantasy about the relationship between humans and machines that animates Westworld. Within the film, the amusement park's simulations of the Wild West and two other "worlds"-Roman World and Medieval World-are made possible by an intricate network of computer technologies. The androids are linked to a command centre where technicians observe all of the activities in the park on computer screens and video monitors (fig. 6). The resemblance to NASA's mission-control room is unmistakable (fig. 7). Crichton claims that one of the inspirations for the film was the against a real human being. Indeed, the entire premise of Westworld is that computers make it possible for each guest "to indulge their every whim" without limits.

This premise was already in the popular imagination by 1973. Three years earlier in Future Shock, Toffler speculated on the impending realization of

simulated environments that offer the customer a taste of adventure, danger, sexual titillation or other pleasure without risk to his real life or reputation. Thus computer experts, roboteers, designers, historians, and museum specialists will join to create experiential enclaves that 


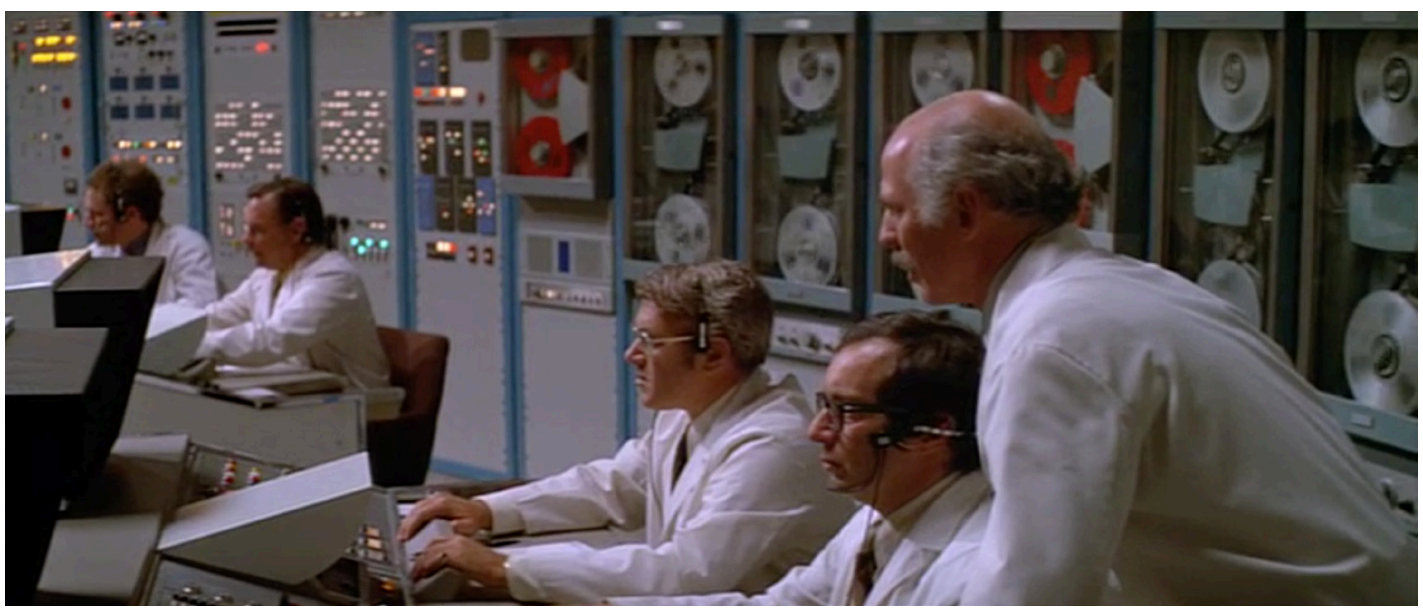

Figure 6. The computer control room in Westworld.

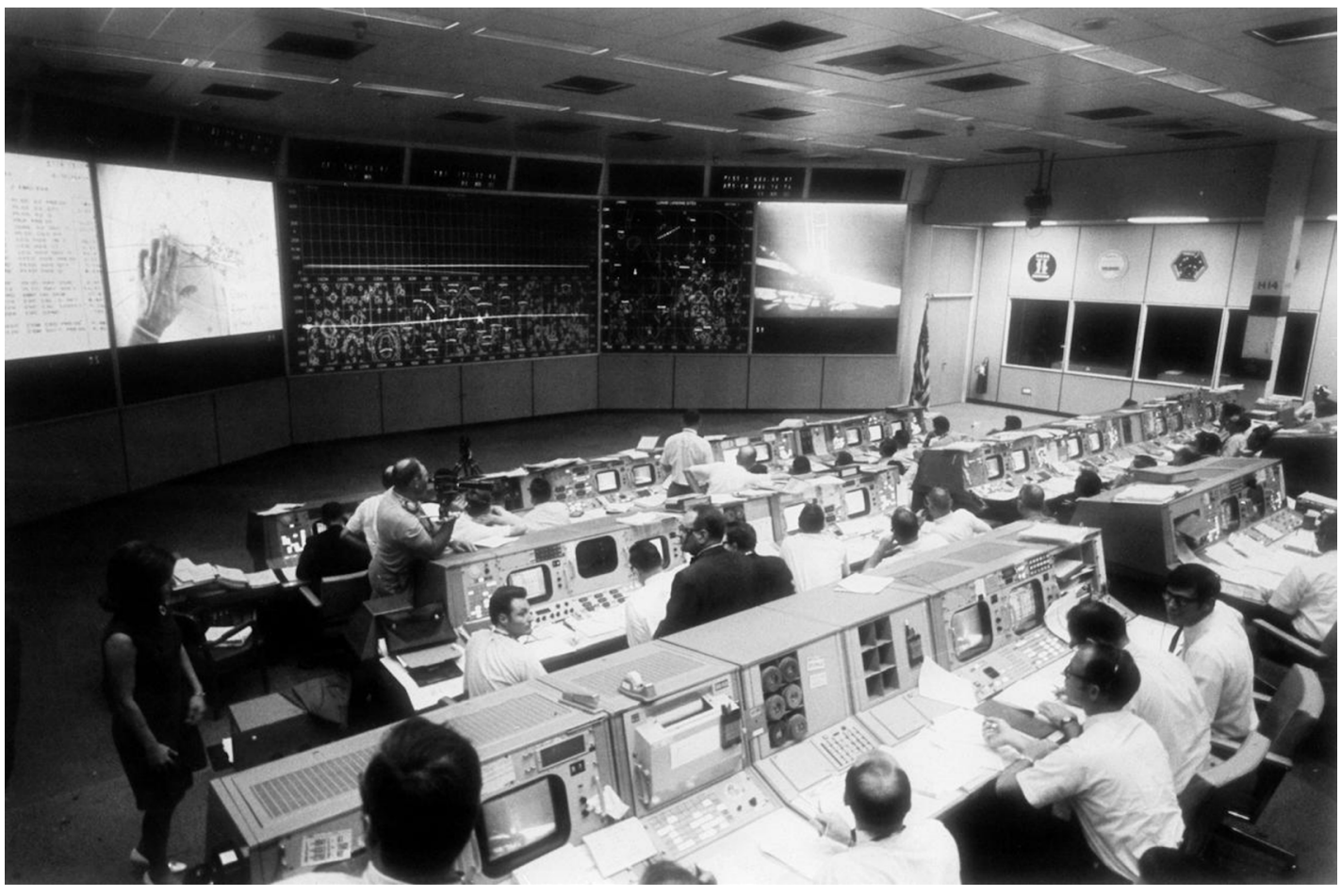

Figure 7. View of Mission Control during lunar surface Apollo 11 extravehicular activity, 1969. Source: NASA Image ID number: S69-39593. 
reproduce, as skillfully as sophisticated technology will permit, the splendor of ancient Rome, the pomp of Queen Elizabeth's court, the "sexoticism" of an eighteenth-century Japanese geisha house, and the like. Customers entering these pleasure domes will leave their everyday clothes (and cares) behind, don costumes, and run through a planned sequence of activities intended to provide them with a first-hand taste of what the original-i.e., unsimulated-reality must have felt like. They will be invited, in effect, to live in the past or perhaps even the future. (228)

Toffler saw such simulated environments taking shape in the ways that artists were beginning to experiment with the uses of electronic media to create immersive and interactive virtual-reality experiences that would continue through the decade. Bracketing the release of Westworld, for example, are computer artist Myron Krueger's pioneering "Psychic Space" (1971) and "Videoplace" (1975), interactive (audio)visual installations that allowed users to control computerized environments by moving through "responsive" spaces outfitted with state-of-the art sensors, cameras, and projectors. ${ }^{5}$

The way that Westworld represents the possibilities of computerized simulations is not only an invocation of these kinds of real and imagined experiments, but it also calls to mind the discourse of power in the history of animation. As Donald Crafton explains, early animated films frequently displayed hands in the act of animating drawings-what he calls the "hand of the artist" motif-to reflect how animators exercise a "god-like" control over their cinematic creations (415). In Westworld, experts wield computers like gods to animate Delos for park visitors. The computerized command centre functions as a kind of omniscient dream machine where engineers and technicians take on the role of all-powerful artists who, like Whitney, have complete creative control over every detail of the park's mise-en-scène. The artists behind the scenes use computers to simulate realistic worlds; puppeteer the androids that make those simulations look and feel so real; surveil and manipulate; fulfill desires; and bend reality itself to the will of those in charge. There is no limit, it would seem, to what humans can do with the computers they created. That is, of course, until the puppets cut their strings.

The robot rebellion that throws Delos into chaos is obvious and inevitable, partly because it was foregrounded in Westworld's marketing campaign, but also because the trope is pervasive in science fiction and animation. Before the gunslinger shoots and kills John, there is growing concern among the park's experts that the machines are malfunctioning - a robotic snake bites John in the desert and a knight stabs a guest - but the aberrant behavior is considered to be a glitch, like a computer virus. When the gunslinger misbehaves, it is clear that the glitch is actually a sign of life and that the machines are not malfunctioning but rather asserting their autonomy from the artist-engineers who created and controlled them. Thus, when we see through the gunslinger's electronic eyes, we are asked to see the android as more than a machine; this is a vision that has a life of its own. We literally see with the computer as it becomes uncontrollable. That this way of seeing the android as a transgressive figure occurred at a time in American history when computers were just beginning to set radical transformations in motion makes the trope of the disobedient machine in Westworld deeply historical. 
It is not coincidental that the spectacle of the robot POV is introduced at the same moment that the utopian fantasy of Delos collapses. When Whitney turned to computers to craft Westworld's special effects, the United States was in the midst of what Carroll Pursell refers to as a "crisis of confidence" about technology (134). The crisis was broadly a shift away from postwar optimism toward "anti-technology views" (172). The views were largely motivated by Cold War uncertainties about uncontrollable technologies and growing fears of experts, corporations, and the military-industrial complex in light of the technological realities and violence in Vietnam. This shift in perception extended as prominently to the machinery of war as it did to computers. In the years between 1971-1973, computer science made unprecedented advances in cybernetics research, the invention of the internet, and the development of microprocessors that gradually made computers available to the public. Views of these innovations were not entirely utopian. Combined with McLuhan's radical critical theories of the electronic-information age and the fact that computers were largely the domain of corporations and government entities rather than of "the people," the computer, Pursell explains, developed a "reputation ... as an impersonaleven antipersonal-force in society" (185).

It is significant that computers were concurrently taken up by science-fiction films and imagined as disobedient machines. In 1974, Vincent Canby reflected in the New York Times on a trend rooted in 2001 and taking shape with films such as Westworld and Richard Heffron's then-anticipated sequel, Futureworld (1976): "The computers of today are the Frankenstein monsters of yesterday's gothic fiction. We are tampering with the Unknown" (8). Quoting Michael Webb of the American Film Institute, the Washington Post reported similarly: "Today's monsters seem to be flashing dials, endless banks of computers whirring silently behind walls of gleaming glass" (Kriegsman $\mathrm{C}_{1}$ ). The narrative structure of Westworld-from freedom to disaster-reads like a roadmap of competing discourses on computers and the broader crisis of confidence taking shape around technology in postwar America. Yet the artists behind Westworld's digital aesthetic also wielded computers to produce wonders, and in this respect the film is as much a futuristic vision of computers in the early 1970 s as it is an experiment in testing their creative powers.

Westworld and/as the Cinema

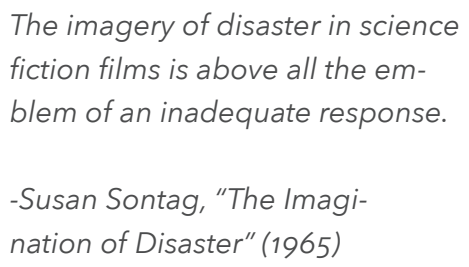

$\mathrm{I}$ $\mathrm{n}$ addition to coinciding with key innovations in the history of computers, Westworld appears at a point in the history of special effects when Hollywood was just beginning to explore the aesthetics of computer-generated imagery (CGI). In the 1960s, computer graphics related to techniques and technologies of the moving image circulated mostly in the realm of experimental animation. Mainstream innovations in what we now call digital special effects did not rise to prominence until the late 1970s and early 1980 s with the use of computer technologies in films such as Star Wars (1977) and Tron (1982). ${ }^{6}$ Westworld thus made its home in an important transitional period in American film history that saw a new cinematic optics emerge from the intersection of older filmmaking practices-namely those 
related to the photorealist tradition-and the digital aesthetics made possible by computers.

From this perspective, Westworld is quite rich as an allegory for the cinema. In a 1973 interview with American Cinematographer, Crichton acknowledged that the premise of the film-visitors living out fantasies in a futuristic amusement park-was deeply cinematic: "In some ways," he explained, "it's a movie about people acting out movie fantasies ... wondering what it would be like to be an actor in an old movie" ("Behind the Scenes" 1397). As
Seven (1960). Brynner apparently wears the same costume in both films (fig. 8).

By weaving a narrative out of androids and amusement parks, Crichton (intentionally or not) taps into two of the cinema's longest standing affinities. With regard to the gunslinger, it is important that the cinematic apparatus was linked from the very beginning, technically and theoretically, to the automaton. As Alan Cholodenko argues, the link is one of the most enduring throughout film history because the automaton's ability to blur the line

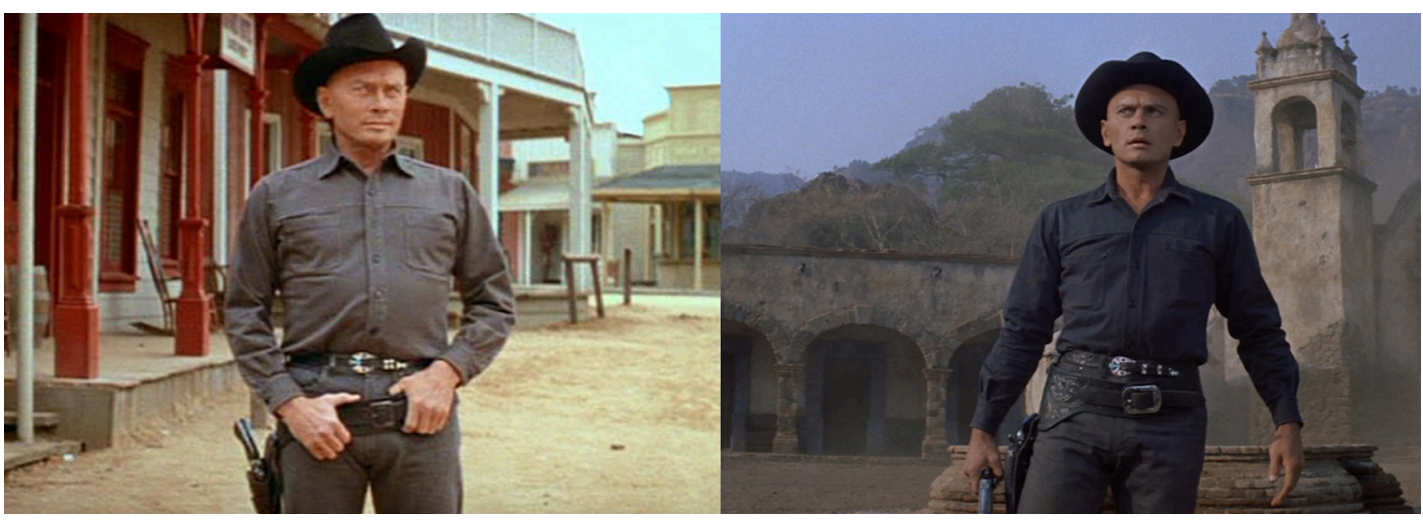

Crichton would have it, when Peter and John visit Westworld they are not simply experiencing a simulation of the Wild West, but stepping into the cinematic Western. Delos is the "old" cinema remade as a "new" immersive virtual-reality system, an updated version of Buster Keaton's dream in Sherlock Jr. (1924) of projecting himself into the movies. The reflexivity in Westworld touches on everything from the resemblance between the computerized command centre and the behind-the-scenes labour on a movie set to the fact that the android gunslinger was played by Yul Brynner, who appeared notably as the gunslinger Chris Adams in John Sturges's Western The Magnificent
Figure 8. Left: Brynner as the android gunslinger in Westworld. Right: Brynner as Chris Adams in The Magnificent Seven.

between human and machine speaks to the very nature of the cinema: they are both "vital machines" capable of producing uncanny illusions of life and motion. In Westworld, for example, the robots are only recognizable as such by their "shimmering" eyes. We have seen how the gunslinger's disobedience makes the android within the film a vital machine, a computer that appears to have a life of its own. The question of vitality is complicated by the fact that, for audiences of Westworld, the android is played by a living human being. Following 
Cholodenko, the gunslinger can also be seen as an embodiment of the cinema, for the cinema is an automaton. ${ }^{7}$

Consider that the special effect Whitney created to simulate the android's vision was made possible by a computer: that is, the computerized robot's vision was in fact computer generated. A curious doubling is at work in Whitney's footage whereby the "real" computerWhitney's-is folded into the "fictional" one, implicating both machines in the narratives of freedom and disaster that play out in the film. There is a nice resonance, for example, between the gunslinger who digitally "reads" the landscape within the film and the computer that "reads" the celluloid image to produce the special effect for the gunslinger's POV. The doubling act is particularly significant in light of the fact that the robot POV is a moving image in transition. Whitney's special-effects sequence was striking in 1973 because it resembled early arcade video-game aesthetics more than anything "cinematic" at the time.

The representation of Delos is doing similar reflexive work. Like automata, amusement parks share a history with the cinema that can be traced to the emergence of motion pictures. Beginning in the $1890 \mathrm{os}$, amusement parks and the cinema co-evolved as emblems of modernity. They were both sites where the novel shocks, dangers, and bewildering experiences of modern life were transformed and put on display as safe, entertaining, and even liberating spectacles. Coney Island, for example, was designed as a virtual city apart-like the Emerald City in $\mathrm{Oz}$-where, John Kasson explains:

[V]isitors were temporarily freed from normative demands. As they disembarked from ferryboats with fanciful names like
Pegasus ... they felt themselves passing
into a special realm of exciting possibility,
a distinctive milieu that encouraged types
of behavior and social interaction that in
other contexts would have been viewed
askance. (41)

The parallels with Crichton's amusement park are revealing. Delos is pitched in the film as "the vacation of the future," where reality is remade into a fantasy and visitors are "free to indulge their every whim" by immersing themselves in a simulated world without limits. The film also opens with a scene that closely resembles Kasson's description of visitors arriving at Coney Island. When we are introduced to Peter and John, they are travelling by hovercraft to Delos. After they disembark from this mechanized Pegasus, they take on new identities as cowboys in Westworld, where they are free to indulge in violence without consequence because reality in Delos is a game. The hovercraft sequence even includes a view from the cockpit that simulates one of the earliest convergences of motion pictures and technologies of virtual travel: the Hale's Tours ride simulators that populated fin-de-siècle amusement parks and World Fairs. ${ }^{8}$

It is remarkable that Westworld should reanimate these affinities amidst a "crisis of confidence" about technology. In Electric Dreamland, Lauren Rabinovitz argues convincingly that at the end of the $19^{\text {th }}$ century "amusement parks and movies taught Americans to revel in a modern sensibility that was about adapting to new technologies" (2). That is, by experiencing the realities of modern life virtually and safely-e.g., as a mechanical ride or a motion picture-people could better adjust to radically new technologies and environments that were, in reality, overwhelming, frightening, 
and potentially disastrous. Angela Ndalianis has argued similarly that, because special effects tend to display broader technological changes during periods of intense innovation, they "have a great deal to do with acclimatizing audiences to different forms of visual engagement" (259). By embedding its special effects in a narrative about automata and an amusement park modeled on fantasies about computers and the cinema, Westworld reads like an education in the rapidly changing technological landscape of its historical moment.

The idea that Westworld is "about adapting to new technologies" is useful for making sense of the film's impulse toward reassurance. Almost as soon as Westworld imagines computers rebelling and threatening humanity it imagines the machines' spectacular destruction: the android gunslinger is ultimately burnt to ashes. The significance of this narrative of (un)controllability is deepened in light of the fact that computers in the 1970s were revolutionizing the relationship between humanity and technology. Cybernetics and philosophy were raising profound questions about what it means to be human, to be conscious, and to be alive. As N. Katherine Hayles has shown, early computers contributed to conceptualizing "humans as information-processing entities who are essentially similar to intelligent machines" (7, original emphasis). In this analogy, the human mind was reimagined as a thing that was not bound to the human body, a "posthuman" idea that gets visualized in Westworld by the robot POV: we transfer our subjectivity to a computer. Although more latent in 1973, computers similarly upended the nature of the cinema when the digital image began to erode the celluloid image's indexical bond to reality, which set in motion a crisis of visuality that continues to unfold today.
Symbolically, then, we might say that the robot POV is what Vivian Sobchack calls a "transitional object," hovering somewhere between the past and the future, utopia and disaster, the familiar and the unfamiliar. Writing about computer animation in WALL-E (Andrew Stanton, 2008), Sobchack proposes that the titular character, a mechanical trash compactor with a microchip core, "serves [in our contemporary moment] as a bridge to the future present of technological development" (387). For Sobchack, WALL-E's embodiment of the old and the new, the mechanical and the electronic, allegorizes and mediates the transition in the cinema from a celluloid past to a digital future. I suggest we read Whitney's special-effect artifact in Westworld similarly as a kind of "bridge" that, although it is ultimately set on fire, mediates an aesthetic and cultural transition shaped by the cinema's intersection with early computer animation techniques. (The parallel that Ingmar Bergman draws in Persona [1966] between the footage of a self-immolation that appears on a television screen and the subsequent melting of the celluloid filmstrip is uncannily resonant here. $)^{9}$

As if haunted by the growing power of computers to pull reality and humanity apart at the seams, the spectacle of the gunslinger's "death" thus seems to invite the audience to bear witness to humanity asserting its definitive control over an increasingly computerized world. A central concern about the ways that computers were revolutionizing life in the early 1970 s was the loosening of what Toffler called "man's grasp on reality" (231). The concern was fueled by a sense that computer technologies were beginning to erode the distinction both between reality and illusion in their capacities for simulation, and between human and machine in their implications for philosophy and biology, 
including the possibility that "life" and "human" would have to be re-imagined if computers were successfully combined with living organic material. The erosion was compounded by the fact that computers were opening the human experience up to infinite new possibilities at a rate that threatened to exceed people's ability to anticipate, let alone control, the short- and long-term effects of the changes taking place: "The problem," in Toffler's view, "is whether [humans] can survive freedom" (187). Considering this, we might say that, if Delos is a computerized "electric dreamland," a virtual space where the freedoms made possible by computers are unleashed, the unravelling of that dreamland is presented as a nightmare from which American audiences can wake up. In delivering this lesson Westworld positions the cinema as a safe space for playing with and alleviating anxieties about frightening technological changes that were already underway in American culture.

Writing in the 196os, Susan Sontag called the trend of "imagining disaster" this way in science fiction an "inadequate response" to reality because it does not oblige audiences to address the very real "terrors" that get fictionalized and resolved in the cinema. Westworld's reassurances no doubt make the film complicit in preserving an illusion of safety in the face of radical changes that radiate outward from film and computers to the fate of humanity itself. The act of covering over can be seen as an attempt to make the uncertainties of modern life bearable, to imagine safety in the ongoing nightmares of the Cold War, for example, when humans were grappling with the possibility of their own self-annihilation, which, as Sontag points out, "could come at any time, virtually without warning" (224). What gets left out, however, is a clear sense that changing the course of scientific and technological innovation is imperative and requires action.

It is precisely what Westworld does not ask audiences to see or do that motived Mead and Applebaum to invoke "the image of some 'madman' igniting himself in front of impassive onlookers" with which I began this article. Drawing a parallel to the Western genre's tendency to mythologize and glorify American imperialism, they criticized Westworld for protecting the American psyche from the dark social and political realities of the early 1970 . While I am primarily concerned with the representation of technology and disaster in Westworld, their indictment is worth quoting at length for what it reveals about the reach of the film's fantasy of control:

It is not [the guests'] conscious awareness that these are robots, non-human machines, that determines their reactions, but rather their feeling and conviction that these "others" are some kind of less-than-human humans, real, living objectifications of their fantasies. So what we have in fact are the beginnings of a rather thinly disguised racial perspective, an exploitation justified by an explanationthe "others" are less than human-and by an economic right-the "guests" pay ... . Nor does it seem coincidental that for the leader of the robot revolt Crichton should cast the former king of Thailand, the leader of the mad Huns, Mexican radical, inscrutable hired killer, the suggestively Mongol-featured Yul Brynner. Along with infrared sensing devices, weapons that kill only the "enemy," willing, thankful prostitutes, etc., Westworld simply provides the triumphant, guiltless hero that Indochina didn't. (12-13) 
Much more can and should be said about Westworld as a kind of racialized war game-Mead and Applebaum offer a fairly thorough discussion of this. Here it is notable that the film's "vacation of the future" premise conjures a related discourse of power in histories of travel in film and related media. Delos's promise of safety and freedom to visitors who embark on futuristic journeys in the park is reminiscent of the kind of mastery promised by amusement parks, World Fairs, and the travelogue genre in the cinema. These other forms of virtual travel are historically wedded-particularly in the early- $20^{\text {th }}$ century-to what Jennifer Peterson calls a "visual imperialism," a mode of representation filtered through "racial perspectives" of colonialism and tourism that rendered foreign and exotic places safe and consumable for Western audiences (8) (see also Ruoff, Virtual Voyages).

This is all to say that Westworld was engaged in a similar kind of cultural work aimed at rendering the "monstrous" and "villainous" computer safe at a time when the effects of that technology were only beginning to come into focus. This dimension of the film betrays the simplicity of its narrative of reassurance, not to mention the simplicity of its special effects. Crichton offers the computer up as a highly seductive machine-like the cinema-with the potential to satisfy an enduring human desire to exceed the limitations of reality and the human experience. The fantasy is a messy one in which the computer emerges as neither utopian nor dystopian; it is an object of debate and a tool Crichton uses to grapple with the difficulty of comprehending what a digital future might look like, and what might become of humanity if it continues to push technological innovation in the direction of that future. The fantasy is also not simply escapist. Westworld works through the cinema to experiment safely with the realities of its unsafe historical moment while covering over a whole range of social and political issues. Looking back on the film from our contemporary moment, the future present that Crichton imagined in 1973 feels very close to home. Given that our networked, media-saturated, and increasingly virtual reality resembles Delos more than it ever has before, we might ask: What kind of work can Westworld do for us now?

The Memory of Reality

$$
\begin{aligned}
& \text { Don't give yourselves to these un- } \\
& \text { natural men-machine men with } \\
& \text { machine minds and machine } \\
& \text { hearts! You are not machines! } \\
& \text {-Charlie Chaplin, The } \\
& \text { Great Dictator (1940) }
\end{aligned}
$$

I n 2016, HBO renewed Crichton's film as a 10-part television series that deviates significantly from the path Westworld imagined in 1973. The new version follows the trajectory of the original, but it unfolds largely from the perspective of the androids, namely a rancher's daughter named Dolores Abernathy (Evan Rachel Wood) and Maeve Millay (Thandie Newton), a madam in a brothel in Westworld. Whereas the gunslinger's POV was an important special effects attraction in Crichton's film, the shift to the android perspective in the $\mathrm{HBO}$ series is primarily a narrative device. Dolores and Maeve are unaware of their machine natures, but as they play out their programmed roles over and over for the park's guests, they slowly become haunted by memories that cause them to question what they consider to be their humanity. Their questioning is profound-What does it mean for a 
machine to feel uncertain about its nature? Or for humans to imagine a machine's uncertainty for that matter? The questioning is also the source of the androids' disobedience: Dolores embarks on a quest to unravel the mystery of her place in Delos, and Maeve arranges her own escape from the park by modifying her programming. Ultimately, it is revealed that one of the park's founders, Robert Ford (Anthony Hopkins), spent decades secretly designing the androids' search for answers that would lead to their rebellion and freedom. Unlike the original Westworld, however, there is no fiery android death; in 2016 the machines win and, as if taking up Chaplin's call, declare their humanity.

While a lengthy analysis of the series is beyond the scope of this article, the manner in which the 2016 version renews the allegorical dimensions of the original is worth mentioning, even if only to open up a dialogue about what the connection reveals about our enduring fascination with that decade and how we are dealing with the "future shock" of our contemporary moment. Most notable here is the fact that the lack of reassurance in HBO's Westworld is pervasive and daunting. Whereas Brynner's gunslinger is cold and mechanical, these new androids are humanized and sympathetic, the tragic victims and playthings of humans who commit acts of murder and sexual violence almost mechanically. Seeing humans mechanized and machines humanized compels us to question our humanity, especially when by the end we might find ourselves rooting, against our nature, for our own demise. To compound the inversion, some characters that we are initially led to believe are human-such as the lead programmer Bernard (Jeffrey Wright) are later revealed to be androids, which makes everyone in Delos suspect. As the machines' existential crises unfold it becomes more and more difficult for them and for us to determine if their questioning is a sign of life or the result of their programming; if the memories that haunt them are real or fake; and if what we are witnessing is occurring in an android's dream or in "reality." The narrative also employs an increasingly ambiguous flashback structure and "reboots" so often that even determining precisely where, when, and if events occurred becomes a challenge. The web of uncertainty is one from which there is apparently no escape for us.

Yet why weave the web? If Peter's destruction of the gunslinger in 1973 is more or less comforting, what is the successful robot rebellion in 2016 doing? The difference no doubt makes the new Westworld more distinctly postmodern than its predecessor. Take, for example, Jean Baudrillard's quite fitting assessment of the spectre that haunts both Westworlds: Disneyland. Writing in 1981 in the light (or shadow) of the impact of electronic media on conceptions of reality, Baudrillard claims, "Disneyland is presented as imaginary in order to make us believe that the rest is real" (12). In other words, humans create "simulations," such as amusement parks, androids, and the cinema, to answer the question of what is "real"-i.e., reality is real because Disneyland is fake. Baudrillard suggests that the faith we place in this distinction covers over the fact that the distinction is imaginary, that there is no "real" and "simulation" but only the "hyperreal" (12-13). Whereas Crichton questions but ultimately preserves this faith-Peter successfully defends reality against the simulation and secures the distinction between both categories-the HBO series seems to be exploring what it would be like to embrace hyperreality, perhaps as a way of 
working through the unique challenges of our historical moment.

In an interview about Westworld (2016), the show's creators Jonathan Nolan and Lisa Joy suggest that their version grapples with the fact that, in the $21^{\text {st }}$ century, humans are living very real lives in the virtual realities made possible by videogames and the internet. Nolan explains:

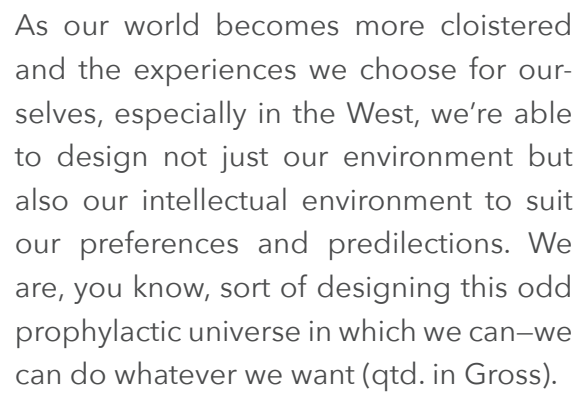

On one level, the idea is that computerized technologies have finally transformed our reality into the Delos that Crichton imagined. On another, we have so thoroughly diffused the real into the electronic phantasmagorias we create that "reality" exists for us in the digital age only as a flickering memory. The Westworld that Nolan and Joy imagined is thus a fraught escape into the plural realities in which we find (or lose) ourselves every time we turn on our TVs, boot up our computers, or pick up our smartphones.

By asking us quite unapologetically to bear witness to the disappearance of reality as we knew it, it may well be that that the dark mirror the $\mathrm{HBO}$ series holds up to us is doing a different kind of work than the original. The series is noticeably less about special effects and more about the impossibility of disentangling humanity from the digital technologies that define how we experience, understand, and "design" our environment, as Nolan puts it. Seeing from the perspective of the androids now is not like imagining seeing through the eyes of an unfamiliar machine-as the computerized robot POV allowed audiences to do in 1973-but like encountering something like our android selves. It is also revealing that the perspective audiences are asked to take now is shifted from the predominantly male cast in 1973 to female leads in 2016, and that many of the central characters in the TV series are people of colour, especially given the prominent lack of diversity in the original film. The new Westworld seems to grapple more openly (although problematically) than the original with the politics of race and gender that are currently playing out, sometimes violently, in the media, in the cinema, and in society in the United States. ${ }^{10}$

It thus cannot be coincidental that Westworld has reappeared at a time when humanity is once again being torn apart at the seams by forces that are increasingly incomprehensible. Just as Mead and Applebaum saw their violent historical moment reflected and refracted in the sublime image of the burning android, we might be haunted by the uncomfortable and quite devastating familiarity of the new Westworld. Particularly in the United States, the techno-scientific realities of surveillance, cyberwarfare, social media, and governance are wreaking havoc in old and new ways on everything from politics, race, gender, and class to civil liberties and the very fabric of culture, if not humanity, itself. Is it any wonder that the first season ends with a striking scene of a diverse android army led by women emerging from the woods on the edge of Westworld seeking violent retribution? (fig. 9) Viewers find no solace in this place because this is not a cinema of reassurance. ${ }^{11}$ Indeed, 
perhaps that is precisely the point: to bring us closer to what Sontag might call an "adequate" response to the terrors and uncertainties of our present realities. If nothing else, when looking out at our Westworld, we should feel the deep urgency of Goethe's question, "Shall the entire house go under?"
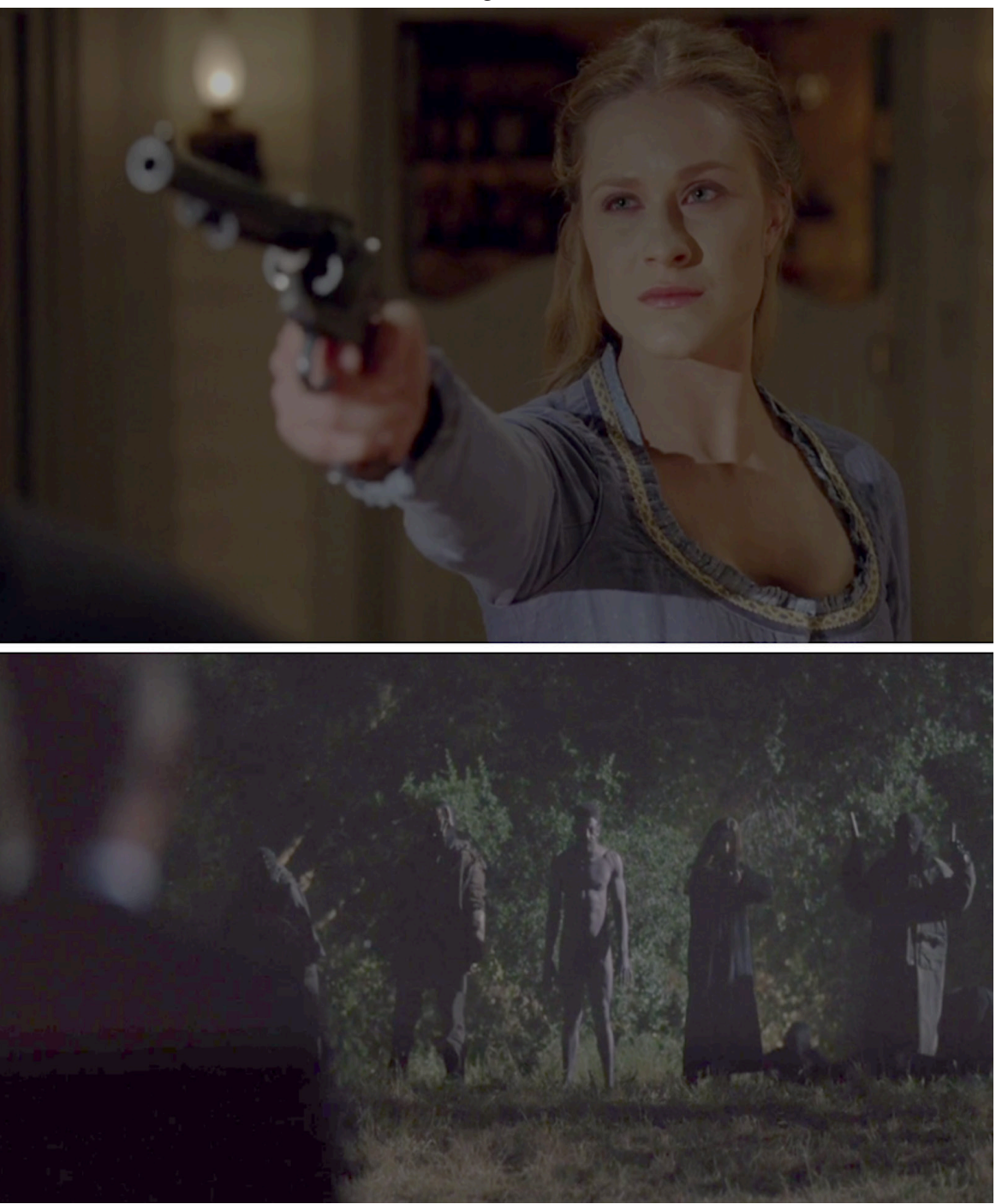

Figure 9. Top: Dolores Abernathy (Evan Rachel Wood) taking aim to assassinate Robert Ford (Anthony Hopkins) and initiating the android revolution. Bottom: The android army emerging from the woods to bring a violent end to humanity. Episode: "The Bicameral Mind."

\section{Works Cited}

Asimov, Isaac. "Escape into Reality." The Humanist vol. 17, no. 6, November-December 1957, pp. 326-332. Print.

Bady, Aaron. "Westworld, Race, and the Western." The New Yorker, 9 December 2016, http:// www.newyorker.com/culture/culture-desk/ how-westworld-failed-the-western.

Baudrillard, Jean. Simulacra and Simulation. The University of Michigan Press, 1994.

"Behind the Scenes of Westworld" American Cinematographer vol. 54, no. 11, November 1973, pp. 13941397, 1420-1423. Print.

“The Bicameral Mind." Westworld. Written by Lisa Joy and Jonathan Nolan, directed by Jonathan Nolan, HBO, 2016.

Bukatman, Scott. "Disobedient Machines." In Beyond the Finite: The Sublime in Art and Science. Edited by Roald Hoffmann and Iain Boyd Whyte, Oxford University Press, 2011, pp. 128-148.

Canby, Vincent. "Movies Are More Sci-Fi Than Ever." New York Times, 17 March 1974, pp. 1, 8.

Cholodenko, Alan. "Speculations on the Animatic Automaton." The Illusion of Life 2: More Essays on Animation, edited by Alan Cholodenko, Power Institute Foundation for Art and Visual Culture, 2007, pp. 486-528.

Crafton, Donald. "Animation Iconography: The 'Hand of the Artist."' Quarterly Review of Film Studies, Fall 1979, pp. 409-428. 
Eisenstein, Sergei. Eisenstein on Disney. Edited by Jay Leyda. Seagull Books, 1986.

Fielding, Raymond. "Hale's Tours: Ultrarealism in the Pre-1910 Motion Picture." Cinema Journal vol. 10, no. 1, Autumn 1970, pp. 34-47.

Galloway, Alexander. Gaming: Essays on Algorithmic Culture. University of Minnesota Press, 2006.

Gross, Terry. Interview with Jonathan Nolan and Lisa Joy. "Westworld' Creators Explore the 'Dark Thrills' of the Digital Age." NPR, 7 November 2016. http://www.npr.org/2016/11/07/501009226/westworld-creators-explore-the-dark-thrills-of-the-digital-age.

Hayles, N. Katherine. How We Became Posthuman: Virtual Bodies in Cybernetics, Literature, and Informatics. University of Chicago Press, 1999.

Kasson, John. Amusing the Million: Coney Island at the Turn of the Century. Hill and Wang, 1978.

Kriegsman, Alan. "Visions of Futures Past: Future Visions." Washington Post 13 May 1971, pp. C1, C4.

Krueger, Myron. "Responsive Environments." AFIPS Conference Proceedings-1977 National Computer Conference, edited by Robert Korfhage, AFIPS Press, 1977, pp. 423-433.

The Magnificent Seven. Directed by John Sturges. Performances by Yul Byrnner, Eli Wallach, and Steve McQueen. The Mirisch Company, 1960.

Manovich, Lev. The Language of New Media. MIT Press, 2001.

McLuhan, Marshall. Understanding Media: The Extensions of Man. The New American Library, Inc., 1964.
Mead, Gerald and Sam Applebaum. "Westworld: Fantasy and Exploitation.” Jump Cut, no. 7, 1975, pp. 12-13.

Musser, Charles and Carol Nelson. High-Class Moving Pictures: Lyman H. Howe and the Forgotten Era of Traveling Exhibition, 1880-1920). Princeton University Press, 1991, p. 55.

Ndalianis, Angela. "Special Effects, Morphing Magic, and the 1990 os Cinema of Attractions." Meta-Morphing: Visual Transformation and the Culture of Quick-Change, edited by Vivian Sobchack, University of Minnesota Press, 200o, pp. 251-271.

Nolan, Jonathan and Lisa Joy, creators. Westworld. HBO, 2018.

Peterson, Jennifer Lynn. Education in the School of Dreams: Travelogues and Early Nonfiction Film. Duke University Press, 2013.

Pursell, Carroll. Technology in Postwar America: A History. Columbia University Press, 2007.

Rabinovitz, Lauren. Electric Dreamland: Amusement Parks, Movies, and American Modernity. Columbia University Press, 2012.

Rogers, Ariel. Cinematic Appeals: The Experience of New Movie Technologies. Columbia University Press, 2013.

Ruoff, Jeffrey, ed. Virtual Voyages: Cinema and Travel. Duke University Press, 2006.

Shilina-Conte, Tatiana. Black Screens, White Frames: Recalculating Film History. 2016. State University of New York at Buffalo, PhD dissertation. 
Sobchack, Vivian. "Animation and Automation, or, The Incredible Effortfulness of Being." Screen vol. 50, no. 4, Winter 2009, pp. 375-391.

Sontag, Susan. "The Imagination of Disaster." Against Interpretation, and Other Essays, Farrar, Straus, and Giroux, 1990, pp. 209-225.

Toffler, Alvin. Future Shock. 1970. Bantam Books, 1984.

Turnock, Julie. Plastic Reality: Special Effects, Technology, and the Emergence of 1970 B Blockbuster Aesthetics. Columbia University Press, 2015. Print.

Westworld. Directed by Michael Crichton, performances by Yul Brynner, Richard Benjamin, and James Brolin. Metro-Goldwyn-Mayer, 1973.

Westworld. The Official Site of Michael Crichton. http://www.michaelcrichton.com/westworld/.

Whissel, Kristen. Spectacular Digital Effects: CGI and Contemporary Cinema. Durham: Duke University Press, 2014. Print.

Whitney, Jr., John. "Creating the Special Effects for Westworld." American Cinematographer, vol. 54, no. 11, November 1973, pp. 1477-148o.

Williamson, Colin. Hidden in Plain Sight: An Archaeology of Magic and the Cinema. New Brunswick: Rutgers University Press, 2015.

\section{Image Notes}

Figure 1. The burning android. Reproduced from Westworld, directed by Michael Crichton (MGM, 1973), DVD.

Figure 2. Theatrical release poster for Westworld (1973). Source: “Westworld." The Official Site of
Michael Crichton. http://www.michaelcrichton. com/westworld/

Figure 3. The rasterized robot POV. Reproduced from Westworld, directed by Michael Crichton (MGM, 1973), DVD.

Figure 4. The gunslinger's view of the tables in the lab where Peter is hiding. Reproduced from Westworld, directed by Michael Crichton (MGM, 1973), DVD.

Figure 5. Bottom half of Mariner 4 photograph of craters on Mars, 1965. Source: NASA Image ID number: Mariner 4, frame ogD.

Figure 6. The computer control room in Westworld. Reproduced from Westworld, directed by Michael Crichton (MGM, 1973), DVD.

Figure 7. View of Mission Control during lunar surface Apollo 11 extravehicular activity, 1969. Source: NASA Image ID number: S69-39593.

Figure 8. Left: Brynner as the android gunslinger in Westworld. Reproduced from Westworld, directed by Michael Crichton (MGM, 1973), DVD. Right: Brynner as Chris Adams in The Magnificent Seven. Reproduced from The Magnificent Seven, directed by John Sturges (The Mirisch Company, 1960), DVD.

Figure 9. Top: Dolores Abernathy (Evan Rachel Wood) taking aim to assassinate Robert Ford (Anthony Hopkins) and initiating the android revolution. Bottom: The android army emerging from the woods to bring a violent end to humanity. Reproduced from Westworld (Season 1, Episode 10), directed by Jonathan Nolan, (HBO, 2016). 


\section{Acknowledgements}

I would sincerely like to thank Nathan Holmes and Andrew Pendakis for their excellent editorial guidance, and two anonymous reviewers for their helpful comments on an early draft of this article. Part of this paper was also presented at the 2018 Society for Cinema and Media Studies Conference in Toronto, and I am grateful for the generous feedback I received from panelists and attendees there, particularly Tanya Shilina-Conte.

\section{Notes}

1 John Whitney, Jr., is the son of the American experimental computer animator John Whitney, Sr. Both were pioneers in early computerized special effects. The avant-garde connection is visible in the abstractness of the gunslinger's POV.

2 For more on iterations of machine perspectives, see also Rogers, Cinematic Appeals.

3 Indeed, Crichton would use the play between animate and inanimate similarly in the context of characters trying to avoid being detected by dinosaurs in his 1990 novel Jurassic Park, which Steven Spielberg adapted for his landmark special effects film three years later.

4 See further Eisenstein 1986 and Manovich 2001.
6 For more on the early computerization of special effects, see Turnock.

7 Martin Scorsese's digital 3D film Hugo (2011) offers an interesting allegory of early cinema as an automaton. For more on this, see Williamson.

8 For more on Hale's Tours, see Rabinovitz 2012 and Fielding 1970.

9 I am very grateful to Tanya Shilina-Conte for bringing this connection to my attention. For more on the parallel between the self-immolation and the burning celluloid in Bergman's film, see Tatiana Shilina-Conte, Black Screens, White Frames: Recalculating Film History, PhD dissertation, State University of New York at Buffalo, 2016.

10 In an outstanding article on the subject, Aaron Bady argues that the $\mathrm{HBO}$ version gestures beyond but ultimately does not escape the Western genre's historical sanctioning of American racism and imperialism.

11 I am borrowing "cinema of reassurance" from Charles Musser and Carol Nelson's description of how Lyman Howe's early-20 ${ }^{\text {th }}$ century travelogues preserved an ideal image of America against the realities of racism and imperialism at the turn of the century.

5 See further Krueger 1977. 